\title{
EFFECTIVENESS OF DIFFERENT CHEMICAL AGENTS IN RAPID DECONTAMINATION OF GUTTA-PERCHA CONES
}

\author{
Celso Luíz Cardoso ${ }^{1 *}$; Roberta Redmerski ${ }^{2}$; Nilza de Lucas Rodrigues Bittencourt ${ }^{1}$ and Cinthia Regiane Kotaka $^{2}$
}

${ }^{1}$ Departamento de Análises Clínicas and ${ }^{2}$ Departamento de Odontologia, Universidade Estadual de Maringá, Maringá, PR, Brasil

Submitted: March 17, 1999; Returned to authors for corrections: July 26, 1999; Approved: January 11, 2000

\section{SHORTCOMMUNIACTION}

\begin{abstract}
The effectiveness of seven disinfectant compounds used in dentistry for a rapid decontamination of 32 guttapercha cones adhered with Staphylococcus aureus, Enterococcus faecalis, Escherichia coli strains or Bacillus subtilis spores was compared. Cones were treated with $2 \%$ glutaraldehyde, $1 \%$ sodium hypochlorite, $70 \%$ ethyl alcohol, $1 \%$ and $0.3 \%$ iodine alcohol, $2 \%$ chlorhexidine, $6 \%$ hydrogen peroxide, and $10 \%$ polyvinylpyrrolidone-iodine, for $1,5,10$, and 15 minutes. After treatment, each cone was transferred to thioglycollate broth and incubated at $37^{\circ} \mathrm{C}$ for 7 days. The products were bactericidal after 1 to 5 minutes and, with exception of ethyl alcohol and iodine-alcohol, sporicidal after 1 to 15 minutes of exposure. Results suggest that chlorhexidine, sodium hypochlorite, polyvinylpyrrolidone-iodine, hydrogen peroxide, and glutaraldehyde were the most effective products in the decontamination of gutta-percha cones.
\end{abstract}

Key words: chemical agents, gutta-percha cones, decontamination.

In endodontic practice, the elimination or the significant reduction of microorganisms from the root canal by chemical and mechanical means is one of the crucial features for a successful treatment $(2,5,24)$. Care must be taken during this procedure to prevent contamination of filling materials to avoid root canal contamination $(1,5,6,8,16,20,21)$.

Gutta-percha cones are now widely used to fill root canals $(5,10)$. However, they are not resistant to conventional sterilization processes in moist or dry heat. Although commercialized in sealed packages, they are not sterile. Thus, to keep the aseptic chain gutta-percha cones require rapid chairside decontamination before use $(2,5,7,9,19)$.

Literature registers several methods for the rapid decontamination of gutta-percha cones in dentistry. Among others, these include the following chemical agents: polyvinylpyrrolidone-iodine (16), glutaraldehyde $(7,15)$, sodium hypochlorite $(3,10,19,21)$, hydrogen peroxide $(17,18)$, chlorhexidine $(22,23)$, quaternary of ammonium $(3,10,12)$ and iodine-alcohol (13). There is, however, no agreement among national or foreign specialists for the best method.

The purpose of this study was to examine the effectiveness of seven compounds commonly used in endodontic practice for the rapid decontamination of gutta-percha cones artificially contaminated with bacterial cells and spores. The compounds were: (i) 2\% glutaraldehyde (Glicolabor Indústria Farmacêutica Ltda., Ribeirão Preto, SP, Brazil); (ii) 1\% sodium hypochlorite solution (Miyako do Brasil Indústria e Comércio Ltda., São Paulo, SP, Brazil), titrated by the iodine/thiosulfate method (25); (iii) $70 \%$ ethyl alcohol prepared at moment of use by mixing 70 $\mathrm{g}$ of absolute ethanol (Merck S.A. Indústrias Químicas, Rio de Janeiro, RJ, Brazil) and $30 \mathrm{~g}$ of distilled water; (iv-v) $0.3 \%$ and $1 \%$ iodine-alcohol prepared at moment of use by dissolving 0.75

\footnotetext{
* Corresponding author. Mailling address: Laboratório de Microbiologia, Bloco I-90, Sala 116, Departamento de Análises Clínicas. Universidade Estadual de Maringá. Avenida Colombo, 5790, CEP 87020-900. Maringá, PR, Brasil. Fax: (+5544) 261-4490. E-mail: deres@maringa.com.br
} 
$\mathrm{g}$ and $2.5 \mathrm{~g}$ of resublimed iodine (Pró-Analyse Indústria Química Ltda., Rio de Janeiro, RJ, Brazil) respectively, in $250 \mathrm{~mL}$ of $70 \%$ ethyl alcohol (Merck); (vi) detergent solution of $2 \%$ chlorhexidine digluconate, containing $2 \%$ ethyl alcohol (Glicolabor Indústria Farmacêutica Ltda., Ribeirão Preto, SP, Brazil); $10 \%$ polyvinylpyrrolidone-iodine (PVP-I) with $1 \%$ of active iodine (Glicolabor Indústria Farmacêutica Ltda., Ribeirão Preto, SP, Brazil); (viii) 6\% hydrogen peroxide (20 volumes) [Shemco Indústria e Comércio, Campinas, SP, Brazil].

Gutta-percha cones Dentsply® \#80 (Dentsply Indústria e Comércio Ltda., Petrópolis, RJ, Brazil) were decontaminated by immersion in a 5\% sodium hypochlorite solution for 30 minutes. The cones were individually and aseptically rinsed with sterile distilled water, and allowed to dry in Petri dishes containing sterile filter paper pads.

The test microorganisms were Staphylococcus aureus ATCC 6538 (experiment 1), Escherichia coli ATCC 25922 (experiment 2), Enterococcus faecalis ATCC 29212 (experiment 3) and Bacillus subtilis spores ATCC 6633 (experiment 4). A suspension of approximately $10^{8} \mathrm{CFU} / \mathrm{ml}$ in tryptic soy broth (Difco Laboratories, Detroit, MI, USA) (bacterial cells) or in distilled water (spores) was used for the contamination of cones. Bacterial suspensions were evaluated in duplicate by the drop-plate technique described by Miles et al. (14), with modifications. Serial decimal dilutions obtained from a mixture of $0.2 \mathrm{ml}$ of inoculum with $1.8 \mathrm{ml}$ of saline solution were used. For each count, three $0.02 \mathrm{ml}$ drops from dilutions $10^{-4}, 10^{-5}, 10^{-6}$ and $10^{-7}$ were poured respectively in each quadrant on the surface of a tryptic soy agar plate (Difco). After drying the inoculum, the plates were incubated at $37^{\circ} \mathrm{C}$ for $24 \mathrm{~h}$, and the drops containing 6 to 60 colonies were selected for counting.

For contamination of gutta-percha cones they were immersed in $20 \mathrm{ml}$ of the bacterial suspension $\left(\sim 10^{8} \mathrm{CFU} / \mathrm{ml}\right)$ for 30 minutes. The cones were transferred to sterile filter paper pads in Petri dishes, and allowed to air-dry for 5 to 10 minutes at room temperature under aseptic conditions.

For experiments 1-4, a series of 64 contaminated guttapercha cones was used. Duplicate cones were transferred individually to sterile $13 \times 100 \mathrm{~mm}$ tubes containing $3 \mathrm{ml}$ of the chemical agent to be tested $(n=8)$ and kept for $1,5,10$ and 15 minutes. Each cone was transferred to $10 \mathrm{ml}$ of thioglycollate broth (Difco), incubated at $37^{\circ} \mathrm{C}$ for 7 days, and observed at 24hour intervals. Bacterial growth in inoculated tubes indicated failure of decontamination and absence of growth showed the antimicrobial activity of the tested agent . Bacterial growth was confirmed by the Gram stain method.

For control of experiments 1-4, 8 decontaminated cones (negative control) and 8 contaminated cones (positive control) were individually cultivated in thioglycollate broth (Difco). Another group of 8 contaminated cones immersed in distillated water from 1, 5, 10 or 15 minutes were also cultured (washing controls). Carryover control was performed as described by Frank and Pelleu (7).

As shown in Fig. 1, 2\% chlorhexidine was the most effective product because all the gutta-percha contaminated cones were decontaminated in 1 minute. The group treated with $1 \%$ sodium hypochlorite and 10\% PVP-I demonstrated bactericidal and sporicidal activity in 5 minutes. A third group treated with $6 \%$ hydrogen peroxide (bactericidal in 5 minutes and sporicidal in 10 minutes) and 2\% glutaraldehyde (bactericidal in 1 minute and sporicidal in 15 minutes). Finally, groups treated with $70 \%$ ethyl alcohol, and $0.3 \%$ and $1 \%$ iodine alcohol were bactericidal in 1 minute, but they did not destroy the spores adhered to the cones surfaces after 15 minutes of exposure.

Carryover control did not show residual toxic effect of tested products and the same number of bacterial cells (experiments 1 to 3 ) or spores (experiment 4) was observed in the control and in carryover tubes, as shown in Table 1.

In our study, the selection of chemical agents $(n=8)$ for decontamination of gutta-percha cones was based on literature data $(3,4,6,7,10,13,15-19,21-23)$ and on results of a recent survey at courses, departments, faculties and schools of dentistry in Brazil with regard the techniques used for the decontamination of gutta-percha cones (11).

Among of the chemical agents tested, $2 \%$ chlorhexidine was the most efficient product. It eliminated both the bacterial cells and spores adhered to the surface of the cones after 1 minute of exposure. These results are consistent to those described by Stabholz et al. (22), who showed that a $1.5 \%$ chlorhexidine digluconate solution was effective within 30 seconds for the disinfection of cones contaminated with staphylococci, streptococci, Bacillus subtilis, Candida krusei and a microbial culture from an infected tooth canal. In another study (23), the efficiency of a $2 \%$ chlorhexidine solution to the gutta-percha cones decontamination in 10 minutes was evidenced, using bacteria from the bucal cavity (Streptococcus mutans and Streptococcus sanguis), intestinal tract (Escherichia coli and Enterococcus faecalis), skin (Staphylococcus aureus) and environment (Bacillus subtilis) as test microorganisms. These results were complemented by the sporicidal activity of $2 \%$ chlorhexidine detected in this study.

The use of sodium hypochlorite for rapid decontamination of gutta-percha cones in endodontic practice was proposed by Senia et al. (19) in 1975. These authors demonstrated that guttapercha cones contaminated with Staphylococcus epidermis, Corynebacterium xerosis, Escherichia coli, and Enterococcus faecalis strains; Bacillus subtilis vegetative cells; and Bacillus subtilis spores were decontaminated after immersion in undiluted Clorox ${ }^{\circledR}$ (5.25\% sodium hypochlorite) for 30,45 and 60 seconds, respectively.

Besides Senia et al. (19), other studies (3, 10, 19, 22) confirmed the efficiency of $5.25 \%$, and $5 \%$ and $4.5 \%$ sodium hypochlorite solutions for the gutta-percha cones 

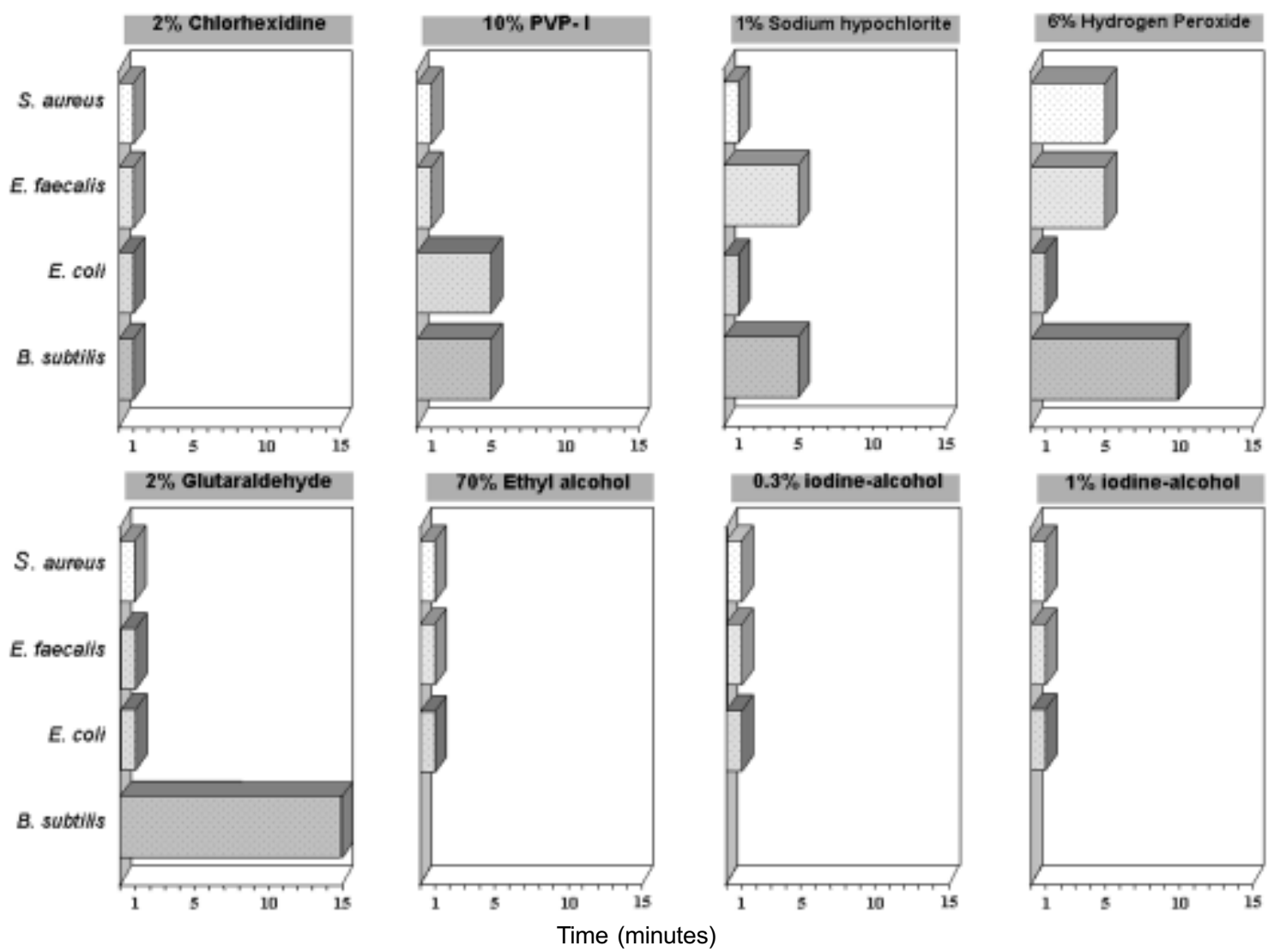

Figure 1. Effectiveness of different chemical agents for 15 minutes decontamination of gutta-percha cones contaminated with bacterial cells (Staphylococcus aureus, Enterococcus faecalis, Escherichia coli) and spores (Bacillus subtilis ).

Table 1. $\log _{10}$ of the mean of two determinations ${ }^{1}$ of viable counts of carryover control for experiments 1 to 4 .

\begin{tabular}{|c|c|c|c|c|c|c|c|c|}
\hline \multirow[t]{2}{*}{$\begin{array}{l}\text { Chemical } \\
\text { Agents }\end{array}$} & \multicolumn{2}{|c|}{$\begin{array}{c}\text { S. aureus } \\
\text { Experiment \#1 }\end{array}$} & \multicolumn{2}{|c|}{$\begin{array}{c}\text { E. coli } \\
\text { Experiment } \# 2\end{array}$} & \multicolumn{2}{|c|}{$\begin{array}{c}\text { E. faecalis } \\
\text { Experiment } \# 3\end{array}$} & \multicolumn{2}{|c|}{$\begin{array}{c}\text { B. subtilis } \\
\text { Experiment \#4 }\end{array}$} \\
\hline & Carryover $^{2}$ & Control $^{3}$ & Carryover & Control & Carryover & Control & Carryover & Control \\
\hline 2\% Chlorhexidine & 5.23 & 5.18 & 5.85 & 5.84 & 5.07 & 5.20 & 3.56 & 3.70 \\
\hline 1\% Sodium Hypochlorite & 5.25 & 5.33 & 5.35 & 5.26 & 5.64 & 6.03 & 3.78 & 3.88 \\
\hline $10 \% \mathrm{PVP}^{4}{ }^{4}$ & 5.14 & 5.18 & 5.63 & 5.70 & 4.79 & 4.62 & 2.66 & 2.82 \\
\hline $6 \%$ Hydrogen Peroxide & 5.36 & 5.30 & 6.73 & 5.87 & 5.12 & 5.05 & 3.56 & 3.52 \\
\hline 2\% Glutaraldehyde & 5.03 & 5.22 & 4.70 & 4.36 & 5.79 & 5.53 & 3.46 & 3.44 \\
\hline $70 \%$ Ethyl Alcohol & 5.17 & 5.10 & 5.53 & 5.51 & 5.20 & 5.26 & 3.34 & 3.65 \\
\hline $0.3 \%$ Iodine-Alcohol & 4.46 & 4.49 & 5.38 & 5.30 & 4.81 & 4.86 & 3.38 & 3.50 \\
\hline 1\% Iodine-Alcohol & 5.22 & 5.35 & 5.93 & 5.57 & 5.52 & 5.11 & 3.45 & 3.06 \\
\hline
\end{tabular}

1. Count in triplicate. Drop-plate technique (Miles et al., 1938).

2. Contaminated cone plus chemical agent-treated cone.

3. Contaminated cone treated with sterile saline solution.

4. $10 \%$ polyvinylpyrrolidone-iodine (with $1 \%$ active iodine) 
decontamination. To our knowledge, there is not register on the efficiency of $1 \%$ sodium hypochlorite solution (Milton's solution) in rapid decontamination of gutta-percha cones. This is the reason why $1 \%$ sodium hypochlorite was included in this study. The results confirmed the efficiency of hypochlorite solution tested.

Use of PVP-I for rapid gutta-percha cones decontamination was suggested by Montgomery in 1971 (16). Gutta-percha cones, contaminated by manipulation during 30 seconds, were used to evaluate the efficiency of a $10 \%$ PVP-I detergent solution $(1 \%$ active iodine) in the disinfection of the contaminated cones after treatments for 10 and 30 seconds and 1, 2, 3, 4, 5 and 6 minutes. After treatment, each cone was transferred to a tube containing $3 \mathrm{ml}$ tryptic soy broth and removed after 5 seconds and placed on blood agar. Cones were carefully rolled on the blood agar surface and the material incubated at $37^{\circ} \mathrm{C}$ during 48 hours. Average number of colonies in the positive control (contaminated cones treated with saline solution) amounted to about 190 . The following microorganisms were identified: Staphylococcus epidermis, Staphylococcus aureus, Flavobacterium diffusum, Bacillus fusiformis and peptostreptococci. Polyvinylpyrrolidoneiodine was effective to destroy all these bacteria after an exposure of 6 minutes. Our results have also shown the sporicidal activity of $10 \%$ PVP-I after treatment of cones for 5 minutes.

Pennachin and Alvares (18) investigated the hydrogen peroxide efficiency in the decontamination of artificially contaminated gutta-percha cones. Cones were immersed and remained during a week in brain heart infusion broth and thioglycollate medium, inoculated with saliva, purulent material obtained from recently extracted teeth or from patients with apical abscesses. $6 \%$ hydrogen peroxide (20 volumes) was effective in the decontamination of cones after 10 minutes of treatment. Results of the present study confirmed these findings.

Gutta-percha cones decontamination method with glutaraldehyde described by Frank and Pelleu (7) in 1983 comprises immersion of the cones in a $2 \%$ glutaraldehyde solution for 5 minutes. In a quantitative study these authors compared the bactericidal and sporicidal action of two $2 \%$ glutaraldehyde solutions commercialized in the USA (Cidex 7®) and Sporocidin $(\mathbb{R})$ and verified that only one was effective. In our study the $2 \%$ glutaraldehyde solution was bactericidal in 1 minute and sporicidal in 15 minutes. The difference in these findings may be due to the chemical constitution of the tested products and the qualitative methodology used in this study.

Although iodine-alcohol is the second indicated chemical agent for the gutta-percha cones decontamination in Brazil (11), no bacteriological study has been found in Brazilian and foreign literature in which artificially contaminated cones were used to evaluate the efficiency of these germicides in endodontic practice. In our study, $0.3 \%$ and $1 \%$ iodine-alcohol showed rapid bactericidal action ( 1 minute) but no sporicidal activity in 15 minutes.
With regard to effectiveness of $70 \%$ ethyl alcohol in rapid gutta-percha cones decontamination, we and other authors (22, 23 ) observed that although a bactericidal activity occurred in 1 minute, this agent was unable to destroy B. subtilis spores adhered to the cones after 15 minutes of exposure.

In summary, the different chemical agents tested in this study were bactericidal in 1 to 5 minutes and, with the exception to the $70 \%$ ethyl alcohol and $0.3 \%$ and $1 \%$ iodine-alcohol, sporicidal in 1 to 15 minutes of the exposure. Results suggest that gutta-percha cones decontamination may be in practice achieved either by $2 \%$ chlorhexidine for 1 minute, or by $1 \%$ sodium hypochlorite and $10 \%$ polyvinylpyrrolidone-iodine during 5 minutes, or by $6 \%$ hydrogen peroxide for 10 minutes or by $2 \%$ glutaraldehyde for 15 minutes.

\section{ACKNOWLEDGMENTS}

We thank Prof. Dr. Thomas Bonnici for revision of the English text.

\section{RESUMO}

\section{Eficácia de diferentes agentes químicos na descontaminação rápida de cones de guta-percha}

Comparou-se a eficácia de sete agentes químicos, usados na prática odontológica, na descontaminação rápida de 32 cones de guta-percha aderidos com Staphylococcus aureus, Enterococcus faecalis, Escherichia coli ou esporos de Bacillus subtilis. Os cones foram tratados por 1, 5, 10 e 15 minutos com glutaraldeído $2 \%$, hipoclorito de sódio $1 \%$, álcool etílico $70 \%$, álcool-iodado $0,3 \%$ e $1 \%$, clorhexidina $2 \%$, água oxigenada $6 \%$ e polivinilpirrolidona-iôdo $10 \%$. Cada cone após o tratamento foi transferido para caldo tioglicolato e incubado a $37^{\circ} \mathrm{C}$ por 7 dias. Os produtos foram bactericidas após 1 a 5 minutos e esporocidas, com exceção do álcool e do álcool iodado, após 1 a 15 minutos de exposição. Os resultados sugerem que a clorhexidina, o hipoclorito, a polivinilpirrolidona-iôdo, a água oxigenada e o glutaraldeído foram os produtos mais eficazes na descontaminação dos cones de guta-percha.

Palavras-chave: agentes químicos, cones de guta-percha, descontaminação.

\section{REFERENCES}

01. Alves, J.A.; Zinet, M.P.A.; Gonçalves, E. N. Novos avanços na microbiologia endodôntica: uma breve revisão. Rev. Paul. Odont., 26: 22-32, 1994.

02. Averbach, R.E. ; Kleir, D.J. Armamentarium and sterilization. In: Cohen, S.; Burns, R. C. (eds). Pathways of the pulp. 6th ed., St. Louis, Mosby, 1994, p.110-127.

03. Clarindo, L.; D’Antonio, G.M. Esterilização rápida de cones de guta-percha por meios químicos. Rev. Gaúcha Odonto., 28: 78-80, 1980. 
04. Cohen, S; Burns, R.C. Endodoncia dos Caminos de la Pulpa. Editora Inter-Médica, Buenos Aires, 1979, p. 67-90.

05. De Deus, Q.D. Endodontia. Editora Médica e Científica Ltda, $5^{a}$ edição, Rio de Janeiro, 1992, p. 219-249, 312-33; 453-461.

06. Doolittle, T.P.; Rubel, R.L.; Fried, I. The effectiveness of common office disinfection procedures for gutta-percha and silver points. N. Y. State Dent. J., 41: 409-414, 1975.

07. Frank, R.J.; Pelleu Jr., G.B. Glutaraldehyde decontamination of guttapercha cones. J. Endodon., 9(9): 368-371, 1983.

08. Holland, R.; Bernabé, P.F.; Nagata, M.J.H.; Mitsuda, S. T. Métodos de esterilização dos cones na endodontia. Rev. Gaúcha Odonto., 38: 133137, 1990.

09. Ingle, J.I.; Bakland, L.K. Endodontics. 4th ed., Malvern, Williams; Wilkins, 1994, p. 608-626.

10. Linke, H.A.B.; Chohayeb, A.A. Effective surface sterilization of guttapercha points. Oral Surg., 55(1): 73-77, 1983.

11. Kotaka, C.R.; Redmerski, R.; Queiroz, A.F.; Cardoso, C.L. Descontaminação rápida de cones de guta-percha na prática endodôntica. Rev. Fac. Odontol. Bauru, 6(2): 73-80, 1998.

12. Kuttler, J. Fundamentos da Endo-Metaendodoncia Practica. Francisco Mendez Oteo Editor e Distribuidor, $2^{\mathrm{a}}$ edición, México D.F., 1980, p. 43 52 .

13. Leonardo, M.R.; Leal, J.M.; Simões Filho, A. P. Endodontia Tratamento de Canais Radiculares. Medicina Panamericana Editora do Brasil Ltda., São Paulo, 1982, p. 296-324.

14. Miles, A.A.; Misra, S.S.; Irwin, J . O. The estimation of the bactericidal power of the blood. J. Hyg., 38: 732-749, 1938.
15. Miller, C.H.; Lu, D.P.; Crimmel, J.E. Bactericidal efficiency of some antimicrobial chemicals. J. Dent. Res., 52: 184, 1973.

16. Montgomery, S. Chemical decontamination of gutta-percha cones with polyvinil-pyrrolidone-iodine. Oral Surg., 31(2): 258-266, 1971.

17. Paiva, J.G.; Alvares, S. Endodontia. Atheneu, $2^{\mathrm{a}}$ edição, São Paulo,1979, p. 302-325.

18. Pennachin, R.; Alvares, S. Cones de guta-percha: sua desinfecção por meios químicos. Rev. Paul. Endod., 2: 4-8, 1981.

19. Senia, E.S.; Marraro, R.V.; Mitchell, J.L.; Lewis, A.G. ; Thomas, L. Rapid sterilization with 5,25\% sodium hypochlorite. J. Endodon., 1: 136-140, 1975.

20. Silva, A.S.; Camargo, H.A.; Ribeiro, J.F.; Fróis, I. M. Ação germicida de alguns agentes químicos usados em endodontia. Rev. Odont. UNESP, São Paulo, 12: 89-91, 1983.

21. Silva, A.S.; De Paiva, J.A.; Antoniazzi, J. H. Avaliação da contaminação do cone de guta-percha durante o seu manuseio de ajuste para obturação de canais radiculares. Rev. Paul. Odont., 10: 46-51, 1988.

22. Stabholz, A.; Stabholz, A.; Friedman, S.; Helling, I.; Sela, M.N. Efficiency of different chemicals agents in decontamination of gutta-percha cones. Int. Endod. J., 20: 211-216, 1987.

23. Suchde, R.V.; Talim, S.T.; Billimoria, K.F. Efficiency of cold sterilizing agent for endodontic procedure. J. Dent. Res., 58: 670, 1979.

24. Tronstad, L. Recent development in endodontic research. Scand. J. Dent. Res., 100: 52-59, 1992.

25. United States Pharmacopeia, 20th ed., Rockville, MD, United States Pharmacopeial Convention, Inc., 1980, 732 p. 